\title{
Productive traits of rye cultivars grown under different sowing seasons
}

\author{
Jéssica A. Kleinpaul ${ }^{1}$, Alberto Cargnelutti Filho², Fernanda Carini ${ }^{1}$, Rafael V. Pezzini ${ }^{1}$, \\ Gabriela G. Chaves ${ }^{1}$ \& Rosana M. Thomasi ${ }^{3}$
}

\begin{abstract}
${ }^{1}$ Universidade Federal de Santa Maria/Programa de Pós-Graduação em Agronomia. Santa Maria, RS, Brasil. E-mail: kleinpauljessica@gmail.com - ORCID: 00000001-7550-6012; carini.fc@gmail.com - ORCID: 0000-0001-6000-7747; rvpezzini@hotmail.com - ORCID: 0000-0003-4134-2499; gabrielachaves94@gmail.com - ORCID: 0000-0001-9461-0288

${ }^{2}$ Universidade Federal de Santa Maria/Departamento de Fitotecnia. Santa Maria, RS, Brasil. E-mail: alberto.cargnelutti.filho@gmail.com (Corresponding author) - ORCID: 0000-0002-8608-9960

${ }^{3}$ Universidade Federal de Santa Maria/Curso de Agronomia/Departamento de Fitotecnia. Santa Maria, RS, Brasil. E-mail: rosanamthomasi@hotmail.com - ORCID: 0000-0001-9248-0213
\end{abstract}

\begin{abstract}
This study aimed to adjust the Gompertz and Logistic nonlinear models for the fresh and dry matter of aerial part and indicate the model that best describes the growth of two rye cultivars in five sowing seasons, as well as to characterize the growth of the cultivars regarding the fresh and dry matter of aerial part. Ten uniformity trials were conducted with the rye crop in 2016. A weekly sampling and evaluation of 10 plants per trial was performed from the time the plants presented one expanded leaf. For each plant, the fresh and dry matter of aerial part were weighed. The Gompertz and Logistic models were adjusted to the accumulated thermal time based on the measures of each trait in each assessment. Also the parameters a, $\mathrm{b}$, and $\mathrm{c}$ for each model were estimated and calculated the interval of confidence for each parameter, as well as the inflection points, maximum acceleration, maximum deceleration and asymptotic deceleration. The quality of the model adjustments was verified using the coefficient of determination, Akaike information criterion, and residual standard deviation. The intrinsic nonlinearity and nonlinearity of the parameter effect was quantified. Both models satisfactorily describe the behavior of the fresh and dry matter of aerial part. The Logistic model best describes the growth of rye cultivars. The growth of the cultivars BRS Progresso and Temprano is distinct between sowing seasons. Cultivar BRS Progresso requires a lower thermal time until reaching $50 \%$ of its growth when compared to the Temprano cultivar.
\end{abstract}

Key words: Secale cereale, growth models, nonlinear models, soil cover plant

\section{Caracteres produtivos de cultivares de centeio sob diferentes épocas de semeadura}

RESUMO: Objetivou-se neste estudo ajustar os modelos não lineares Gompertz e Logístico, para as massas de matéria fresca e seca de parte aérea e indicar o modelo que melhor descreve o crescimento de duas cultivares de centeio em cinco épocas de semeadura e caracterizar o crescimento das cultivares em relação às massas de matéria fresca e seca de parte aérea. Dez ensaios de uniformidade foram conduzidos com a cultura do centeio no ano de 2016. A partir do período que as plantas apresentavam uma folha expandida, iniciou-se, semanalmente, a coleta e avaliação de 10 plantas de cada ensaio. Em cada planta foram pesadas as massas de matéria fresca e seca de parte aérea. Foram ajustados os modelos Gompertz e Logístico em função da soma térmica acumulada, a partir das médias de cada caractere, em cada avaliação. Também, estimaram-se os parâmetros a, b e c para cada modelo e calculou-se o intervalo de confiança para cada parâmetro e os pontos de inflexão, aceleração máxima, desaceleração máxima e desaceleração assintótica. A qualidade do ajuste dos modelos foi verificada pelo coeficiente de determinação, critério de informação de Akaike e desvio padrão residual. Foi quantificada a não linearidade intrínseca e a não linearidade do efeito dos parâmetros. Ambos os modelos descrevem satisfatoriamente o comportamento das massas de matéria fresca e seca da parte aérea. $\mathrm{O}$ modelo Logístico descreve melhor o crescimento das cultivares de centeio. O crescimento das cultivares BRS Progresso e Temprano é distinto entre as épocas de semeadura. A cultivar BRS Progresso necessita menor soma térmica até atingir 50\% de seu crescimento quando comparada com a cultivar Temprano.

Palavras-chave: Secale cereale, modelos de crescimento, modelos não lineares, planta de cobertura de solo 


\section{INTRODUCTION}

Rye (Secale cereale L.) is a cereal grown in cold climate regions. The crop can be used for both soil cover and grain production, presenting high dry matter productivity with values of $12 \mathrm{Mg} \mathrm{ha}^{-1}$ (Meinerz et al., 2011), aiding to increase retention and available water in the soil (Basche et al., 2016).

It is essential to define cultivars and sowing seasons that provide adequate plant growth and development to maximize productivity gains. Cultivars tend to behave differently when crops are sown at different sowing seasons given that the cultivar is exposed to different environmental conditions. In this sense, more accurate information can be gained by studying the behavior of crops through growth models for each sowing condition since the behavior of different cultivars and traits can be better analyzed.

Mathematical models can characterize crops allowing to understand its growth pattern. In agriculture, the models assist in crop management under different environmental conditions, as well as in assessing the contribution of the parts of the plant to their final growth (Dourado Neto et al., 1998).

Among the nonlinear mathematical models, the Gompertz and Logistic models are the most used to describe plant growth behavior based on the observation of the crop itself. Thus, these models have been adjusted to assess coffee fruit growth curves (Fernandes et al., 2014), cashew fruit development (Muianga et al., 2016), and cocoa fruit growth (Muniz et al., 2017).

The adjustment of nonlinear models can aid in understanding the growth pattern of rye and the response of the traits depending on the sowing season. Therefore, it is assumed that the Gompertz and Logistic models fit the productive traits and satisfactorily describe the growth of two rye cultivars in five sowing seasons, allowing to select the most appropriate model. Thus, the objectives of this study were to adjust the nonlinear Gompertz and Logistic models for the fresh and dry matter of aerial part and indicate the model that best describes the growth of two rye cultivars in five sowing seasons, as well as to characterize the behavior of the cultivars regarding the fresh and dry matter of aerial part.

\section{Material ANd Methods}

Ten uniformity trials (blank experiments) using rye (Secale cereale L.) were conducted in the experimental area of the Departamento de Fitotecnia da Universidade Federal de Santa

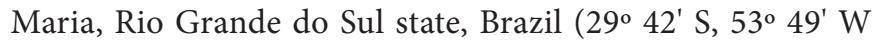
and $95 \mathrm{~m}$ of altitude), in the 2016 harvest. According to the Köppen classification, the climate of the region is Cfa - humid subtropical, with no summers and no defined dry season (Heldwein et al., 2009). The soil was classified as an Ultisol.

Two rye cultivars were sown in five sowing seasons. Thus, each cultivar in each sowing season constituted an uniformity trial. The sowing seasons occurred on May $3^{\text {rd }}$, May $25^{\text {th }}$, June $7^{\text {th }}$, June $22^{\text {nd }}$ and July $4^{\text {th }}, 2016$, representing sowing seasons $1,2,3,4$ and 5, respectively, contemplating sowing seasons indicated or not for the crop. The months of June and July are indicated for sowing cultivars for grain production, while the best season for soil cover and grazing cultivars are April and May. The soil was conventionally prepared with light harrowing and basic fertilization of $25 \mathrm{~kg} \mathrm{ha}^{-1}$ of $\mathrm{N}, 100 \mathrm{~kg} \mathrm{ha}^{-1}$ of $\mathrm{P}_{2} \mathrm{O}_{5}$ and $100 \mathrm{~kg} \mathrm{ha}^{-1}$ of $\mathrm{K}_{2} \mathrm{O}$ in each sowing.

The BRS Progresso and Temprano cultivars were sown by throwing the seeds. These cultivars were chosen for their distinct characteristics, i.e., one intended for grain production (BRS Progresso) and the other for soil cover and grazing (Temprano). The area used for each cultivar in the first sowing season presented $320 \mathrm{~m}^{2}(20 \times 16 \mathrm{~m})$, while the area used for the remaining seasons presented $375 \mathrm{~m}^{2}(25 \times 15 \mathrm{~m})$.

Ten plants were randomly chosen for each trial, using a digital scale to weigh the fresh matter of aerial part (FM, in $\left.\mathrm{g} \mathrm{plant}^{-1}\right)$ and dry matter of aerial part (DM, in $\left.\mathrm{g} \mathrm{plant}^{-1}\right)$. The plants were conditioned in paper packages, placing these in a forced ventilation oven at $60^{\circ} \mathrm{C}$ until reaching a constant mass to obtain the dry matter of aerial part, subsequently weighing the mass.

The assessments were performed during the period from the first fully expanded leaf, stage 1 (Large, 1954) to October $27^{\text {th }}$ (seasons 1, 2 and 3), November $3^{\text {rd }}$ (season 4), and November $18^{\text {th }}$ (season 5), for the trials with the BRS Progresso cultivar and until November $3^{\text {rd }}$ (season 1$)$, September $21^{\text {st }}$ (season 2), October $7^{\text {th }}$ (season 3), October $27^{\text {th }}$ (season 4), and November $10^{\text {th }}$ (season 5) with the Temprano cultivar. For fresh and dry matter of aerial part, 15 assessments were conducted using cultivar BRS Progresso at seasons 1, 2, 3, 4 and 5. For the Temprano cultivar, 18, 15, 15, 16 and 16 assessments were conducted, at seasons 1, 2, 3, 4 and 5, respectively.

The minimum and the maximum air temperatures were obtained in ${ }^{\circ} \mathrm{C}$, for the period from the implementation of the experiment to the end of the assessments from the records of the Meteorological Station of the Universidade Federal de Santa Maria, located $50 \mathrm{~m}$ from the experimental area. With these data, the daily thermal time was calculated using the Gilmore \& Rogers (1958) and Arnold (1960) method through Eq. 1:

$$
\mathrm{TTd}=\left(\frac{\mathrm{Tmax}+\mathrm{T} \min }{2}-\mathrm{Tb}\right)
$$

in which:

TTd - daily thermal time, ${ }^{\circ} \mathrm{C}$;

Tmax - maximum daily air temperature, ${ }^{\circ} \mathrm{C}$;

Tmin - minimum daily air temperature, ${ }^{\circ} \mathrm{C}$; and,

$\mathrm{Tb}$ - base temperature of the rye, of $0{ }^{\circ} \mathrm{C}$ (Bruckner \& Raymer, 1990).

After which the accumulated thermal time was calculated using Eq. 2:

$$
\mathrm{TTa}=\sum \mathrm{TTd}
$$

in which:

TTa - accumulated thermal time; and,

$\Sigma$ TTd - sum of the daily thermal time.

In each trait (dependent variable) the average values of the 10 plants from each evaluation were used subsequently adjusting the nonlinear Gompertz (Windsor, 1932) (Eq. 3) and Logistic (Nelder, 1961) models for each uniformity trial (Eq. 4) (Table 1) in function of the accumulated thermal time (independent variable). 
Table 1. Gompertz and Logistic model equations ${ }^{(1)}$, inflection point (IP), maximum acceleration point (MAP), maximum deceleration point (MDP) and the asymptotic deceleration point (ADP)

\begin{tabular}{|c|c|c|c|c|c|c|}
\hline & \multicolumn{4}{|c|}{$\begin{array}{c}\text { Gompertz } \\
\mathrm{y}=\mathrm{a} \exp [-\exp (\mathrm{b}-\mathrm{cx})]\end{array}$} & \multicolumn{2}{|c|}{$\begin{array}{c}\text { Logistic } \\
y=a /[1+\exp (-b-c x)](4)\end{array}$} \\
\hline & $x$ & & $y$ & & $x$ & $y$ \\
\hline $\mathbb{P}$ & $\frac{b}{c}$ & (5) & $\frac{\mathrm{a}}{\mathrm{e}}$ & (6) & $\frac{-b}{c}$ & (8) \\
\hline MAP & $\frac{\mathrm{b}-\ln \left(\frac{3+\sqrt{5}}{2}\right)}{c}$ & (9) & $a \exp \left(-\frac{3+\sqrt{5}}{2}\right)$ & (10) & $\frac{1}{c}[-b-\ln (2+\sqrt{3})]$ & $\frac{a}{3+\sqrt{3}}(12)$ \\
\hline MDP & $\frac{\mathrm{b}-\ln \left(\frac{3-\sqrt{5}}{2}\right)}{\mathrm{c}}$ & (13) & $a \exp \left(-\frac{3-\sqrt{5}}{2}\right)$ & (14) & $\frac{1}{c}[-b-\ln (2-\sqrt{3})]$ & $\frac{a}{3-\sqrt{3}}(16)$ \\
\hline ADP & $\frac{\mathrm{b}-\ln (36.8-9.77 \sqrt{14.06}}{\mathrm{c}}$ & (17) & $a \exp [-(36.8-9.77 \sqrt{14}$ & (18) & $\frac{1}{c}[-b-\ln (5-2 \sqrt{6})](19)$ & $\frac{a}{2(3-\sqrt{6})}(20)$ \\
\hline
\end{tabular}

${ }^{(1)} \mathrm{y}$ - Dependent variable (trait); $\mathrm{x}$ - Independent variable (accumulated thermal time); $\mathrm{a}$ - Asymptotic value; $\mathrm{b}$ - Ratio between initial growth value and final value; $\mathrm{c}$ - Maximum relative growth rate; exp - Base of the neperian logarithm

The assumptions of the mathematical models were verified based on the residuals, thus verifying the normality of the residues through the Shapiro-Wilk test, the presence of autocorrelation in the residues through the Durbin-Watson test, and the homoscedasticity of the residues through the Breusch-Pagan test.

To adjust the models, the following calculations were performed: inflection point (IP) (Eqs. 5, 6, 7 and 8), the maximum acceleration point (MAP) (Eqs. 9, 10, 11 and 12), the maximum deceleration point (MDP) (Eqs. 13, 14, 15 and 16) and the asymptotic deceleration point (ADP) (Eqs. 17, 18, 19 and 20) for each model (Mischan \& Pinho, 2014) (Table 1).

The parameters were compared between the cultivars (BRS Progresso versus Temprano) in each sowing season for each model (Gompertz and Logistic) and between sowing dates in each cultivar (BRS Progresso and Temprano).

It was adopted the criterion of overlapping the intervals of confidence of the estimated parameters to compare the Gompertz and Logistic models. To do this, the lower and upper limits of the $95 \%$ interval of confidence were calculated. The comparison was done by verifying whether or not the respective intervals coincided. Thus, the cultivars do not differ if at least one estimate of the parameter ( $a, b$ or $c$ ) of a trait for a given cultivar is contained between the lower and upper limits of the parameter interval of confidence of the other cultivar. On the other hand, the parameter estimates differ between cultivars if none of the estimates are contained between the lower and upper limits of the parameter interval of confidence of the other cultivar. This methodology was also used to compare sowing dates.

In choosing the appropriate models for each trait, the adjustment quality evaluators were determined, which are: coefficient of determination ( $\mathrm{R}^{2}$ - Eq. 21), in which high values of $\mathrm{R}^{2}$ are desired for a better adjustment; Akaike information criterion (AIC - Eq. 22), for which a lower value represents a better adjustment; and residual standard deviation (RSD - Eq. 23), for which low values also represent a better adjustment, obtained by the following equations:

$$
\begin{gathered}
\mathrm{R}^{2}=1-\frac{\mathrm{SSR}}{\mathrm{TSS}} \\
\mathrm{AIC}=\frac{\ln \left(\sigma^{2}\right)+2(\mathrm{p}+1)}{\mathrm{n}}
\end{gathered}
$$

$$
\mathrm{RSD}=\sqrt{\frac{\mathrm{SSR}}{\mathrm{n}-\mathrm{p}}}
$$

in which:

SSR - square sum of the residues;

TSS - total square sum;

$\ln \left(\sigma^{2}\right)$ - logarithm of the error variance;

p - number of parameters of the model; and,

$\mathrm{n} \quad$ - number of assessments.

To analyze the behavior of nonlinear models, Ratkowsky (1983) recommends analyzing the nonlinearity measurements of Bates \& Watts (1988) curvatures. Thus, these authors quantified the nonlinearity present in the models, decomposing it into intrinsic nonlinearity (IN) and parameter effect nonlinearity $(\mathrm{PE})$ based on the geometric concept of curvature. Thus, to choose the most appropriate model to describe the growth of a crop, the model with the lowest values of both intrinsic and parameter effect nonlinearity was choosen.

The statistical analyses was conducted using the Microsoft Office Excel $^{\circledR}$ application and the R statistical software ( R Development Core Team, 2018).

\section{Results ANd Discussion}

The normality, independence and homogeneity assumptions of the residues were met regarding the fresh and dry matter of aerial part, in the Gompertz and Logistic models using the BRS Progresso and Temprano cultivars, in five sowing seasons (Table 2) as also occurred in Fernandes et al. (2014), in which the assumptions were met for the accumulation of fresh matter of coffee fruits.

As an example of the comparison between the interval of confidence overlap criterion for the fresh matter of aerial part, in the comparison between the parameter estimates, the one obtained by the Gompertz model between the BRS Progresso and Temprano cultivars, in season 2 , showed that the estimate for parameter a (63.87936) of cultivar BRS Progresso is within the interval of confidence of the estimate of parameter a (46.89203) of cultivar Temprano, i.e., between the lower (6.90279) and upper (86.88127) limits. It was also found that the estimate of parameter a (46.89203) of cultivar Temprano is outside the interval of confidence of the estimate of parameter a (63.87936) of cultivar BRS Progresso, i.e., it is outside the lower 
Table 2. P-value of the Shapiro-Wilk (SW), Durbin-Watson (DW) and Breusch-Pagan (BP) tests applied on the Gompertz and Logistic model residues for traits as a function of accumulated thermal time $\left({ }^{\circ} \mathrm{C}\right)$ of cultivars BRS Progresso and Temprano in five sowing seasons of rye

\begin{tabular}{|c|c|c|c|c|c|c|c|c|c|c|c|c|c|}
\hline \multirow{2}{*}{ Trait ${ }^{(1)}$} & \multirow{2}{*}{ Cultivar } & SW & DW & $\mathrm{BP}$ & SW & DW & $\mathrm{BP}$ & SW & DW & BP & SW & DW & BP \\
\hline & & \multicolumn{3}{|c|}{ Gompertz } & \multicolumn{3}{|c|}{ Logistic } & \multicolumn{3}{|c|}{ Gompertz } & \multicolumn{3}{|c|}{ Logistic } \\
\hline & & \multicolumn{6}{|c|}{ Season1 (May 3, 2016) } & \multicolumn{6}{|c|}{ Season4 (June 22, 2016) } \\
\hline \multirow{2}{*}{$\mathrm{FM}$} & BRS Progresso & 0.743 & 0.360 & 0.073 & 0.543 & 0.382 & 0.050 & 0.137 & 0.050 & 0.117 & 0.075 & 0.050 & 0.122 \\
\hline & Temprano & 0.050 & 0.050 & 0.061 & 0.050 & 0.050 & 0.114 & 0.096 & 0.370 & 0.132 & 0.055 & 0.318 & 0.120 \\
\hline \multirow{3}{*}{ DM } & BRS Progresso & 0.076 & 0.292 & 0.050 & 0.143 & 0.226 & 0.050 & 0.050 & 0.748 & 0.050 & 0.050 & 0.872 & 0.054 \\
\hline & Temprano & 0.050 & 0.800 & 0.050 & 0.055 & 0.914 & 0.050 & 0.061 & 0.584 & 0.125 & 0.107 & 0.944 & 0.094 \\
\hline & & \multicolumn{6}{|c|}{ Season2 (May 25, 2016) } & \multicolumn{6}{|c|}{ Season5 (July 4, 2016) } \\
\hline \multirow{2}{*}{ FM } & BRS Progresso & 0.775 & 0.454 & 0.101 & 0.302 & 0.510 & 0.120 & 0.149 & 0.050 & 0.153 & 0.070 & 0.050 & 0.120 \\
\hline & Temprano & 0.050 & 0.812 & 0.050 & 0.050 & 0.676 & 0.050 & 0.460 & 0.816 & 0.134 & 0.471 & 0.982 & 0.114 \\
\hline \multirow{2}{*}{ DM } & BRS Progresso & 0.050 & 0.162 & 0.160 & 0.050 & 0.068 & 0.071 & 0.701 & 0.434 & 0.107 & 0.242 & 0.426 & 0.102 \\
\hline & Temprano & 0.290 & 0.804 & 0.050 & 0.459 & 0.606 & 0.050 & 0.850 & 0.226 & 0.162 & 0.653 & 0.100 & 0.084 \\
\hline \multicolumn{14}{|c|}{ Season3 (June 7, 2016) } \\
\hline \multirow{2}{*}{$\mathrm{FM}$} & BRS Progresso & 0.358 & 0.050 & 0.085 & 0.318 & 0.050 & 0.074 & & & & & & \\
\hline & Temprano & 0.377 & 0.280 & 0.050 & 0.609 & 0.348 & 0.104 & & & & & & \\
\hline \multirow{2}{*}{$\mathrm{DM}$} & BRS Progresso & 0.438 & 0.050 & 0.088 & 0.318 & 0.050 & 0.074 & & & & & & \\
\hline & Temprano & 0.297 & 0.206 & 0.050 & 0.377 & 0.314 & 0.350 & & & & & & \\
\hline
\end{tabular}

(54.53429) and upper (73.22442) limits. In this example, since at least one estimate of parameter a of one cultivar is within the interval of confidence of the estimate of the other cultivar, it is concluded that the estimate of parameter a (63.87936) of cultivar BRS Progresso does not differ from the estimate of parameter a (46.89203) of the Temprano cultivar (Table 3).

Table 3. Estimates of the parameters ( $a, b$, and c), lower limit (LL) and upper limit (UL) of the confidence interval (CI ${ }_{95 \%}$ ) of the Gompertz and Logistic models for traits as a function of accumulated thermal time $\left({ }^{\circ} \mathrm{C}\right)$ of cultivars BRS Progresso and Temprano in five sowing seasons of rye (Secale cereale L.)

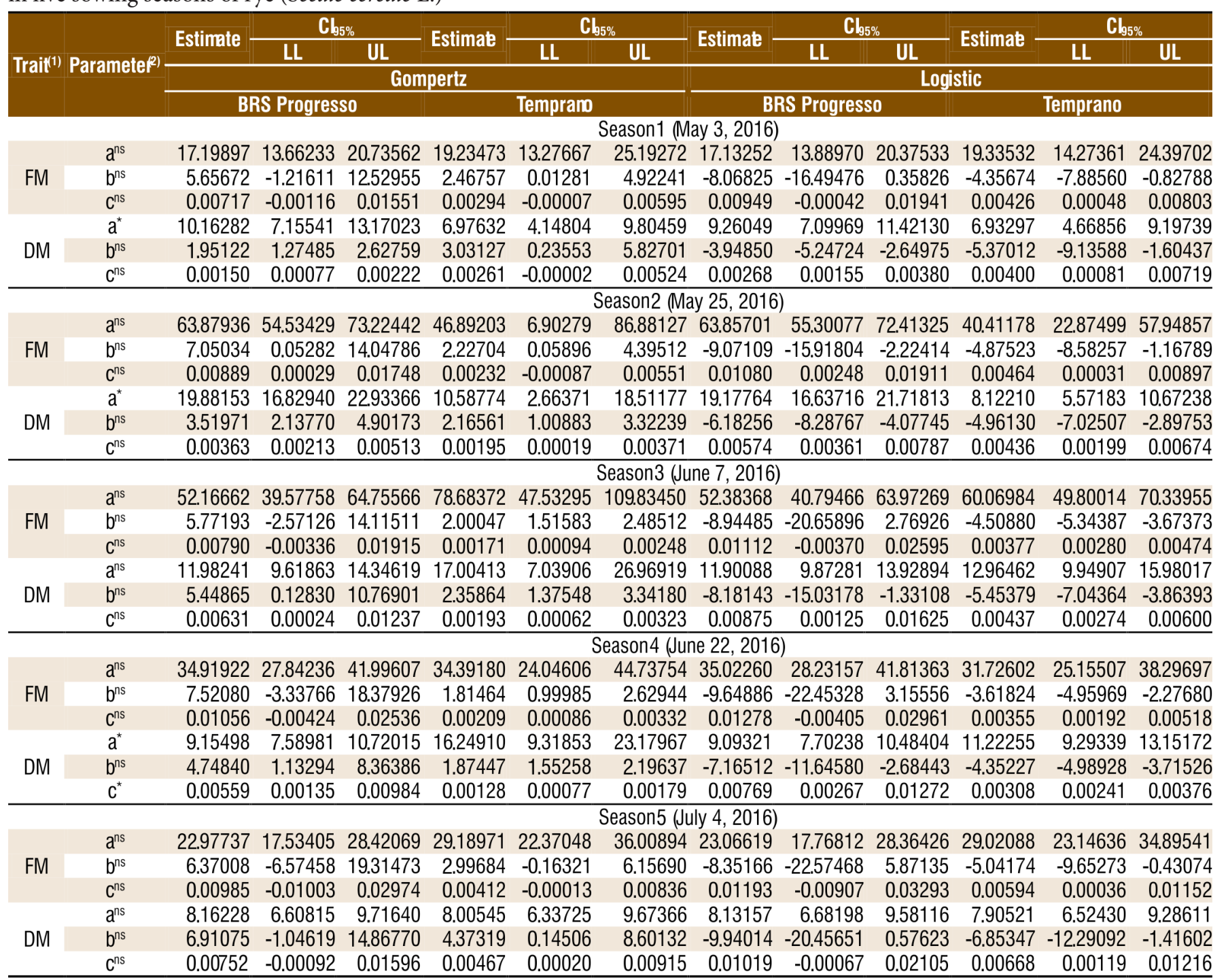

${ }^{(1)}$ Fresh matter of aerial part $\left(\mathrm{FM}\right.$, in $\left.\mathrm{g} \mathrm{plant}^{-1}\right)$ and dry matter of aerial part (DM, in $\left.\mathrm{g} \mathrm{plant}^{-1}\right)$;

${ }^{\left({ }^{2}\right)}$ Comparison of the estimates of the parameters $(\mathrm{a}, \mathrm{b}$ and $\mathrm{c})$ between the cultivars: "Estimates differ at $\mathrm{p} \leq 0.05$. ${ }^{\mathrm{ns}}$ Not significant 
For the fresh matter of aerial part, it is inferred that the behavior among all parameter estimates ( $a, b$ and $c$ ) of the Gompertz and Logistic models was equal in seasons 1, 3 and 4 when comparing between cultivars in each sowing season (Table 3). In other words, in the field, these cultivars present similar behavior in the mentioned sowing dates. Similar behavior occurred for the dry matter of aerial part, but in seasons 1, 2, 3 and 5, all parameter estimates showed the same behavior when comparing the models between cultivars at each sowing season. Therefore, it can be affirmed that the behavior of these cultivars compared within each sowing season is similar.

By analyzing the estimates of the parameters of the Gompertz and Logistic models between sowing dates in each cultivar (Table 4), it is observed that the maximum value that the plants accumulate in fresh and dry matter of aerial part is distinct among most sowing dates in each cultivar.

For the Gompertz and Logistic models, estimates of parameters b and c differ at 0.05 of significance only between sowing dates 1 and 2 in cultivar BRS Progresso for dry matter of aerial part (Table 4). These results show that the growth of cultivars BRS Progresso and Temprano is distinct between these sowing dates, presenting different transition times in the growth speed and maximum growth rate, i.e., the behavior of the cultivars in the field is different and the growth speed of cultivar BRS Progresso is superior to that of cultivar Temprano. Therefore, since most comparisons of the estimates of parameters $b$ and $c$ are not significant between sowing dates in each cultivar, the model can be used for any sowing date, given that it has the same growth behavior.

The inflection points, maximum acceleration, maximum deceleration and asymptotic deceleration were used to infer on the crop growth. The inflection point for both the Gompertz and Logistic models regarding the fresh and dry matter of aerial part indicates that the cultivar BRS Progresso requires lower thermal time for the crop to reach $50 \%$ of its growth when compared with the Temprano cultivar (Table 5). When comparing the models, in the Gompertz model, cultivars BRS Progresso and Temprano reach their maximum growth rates with lower thermal time when compared to the growth rates of the cultivars in the Logistic model, apart from the dry matter of aerial part in season 4 (cultivar Temprano). However, in the Logistic model, the plants with higher thermal sum reached the inflection point with higher fresh and dry matter of aerial part, apart from season 4 (cultivar Temprano). Deprá et al. (2016) also found different inflection point values between cultivars and progenies when analyzing the traits of corn cultivars and progenies in function of thermal time.

By analyzing the other points, it is possible to observe a behavior similar to that described for the inflection point, allowing to infer the requirement of a lower thermal time to reach the maximum growth rate in the cultivar BRS Progresso compared with the cultivar Temprano when using the Logistic model (Table 5). Thus, since the cultivars have different production purposes, the thermal time requirements are also different between cultivars. Therefore, because cultivar BRS Progresso has a shorter cultivation cycle, it requires less thermal time to achieve grain production, while the Temprano
Table 4. Comparison of the estimates of the parameters (a, $b$, and c) between sowing seasons ${ }^{(1)}$ based on the confidence interval $\left(\mathrm{CI}_{95 \%}\right)$ of the Gompertz and Logistic models for traits ${ }^{(2)}$ as a function of the accumulated thermal time $\left({ }^{\circ} \mathrm{C}\right)$ of cultivars BRS Progresso and Temprano in five sowing seasons of rye

\begin{tabular}{|c|c|c|c|c|c|c|c|c|c|}
\hline \multirow{3}{*}{ Season } & \multirow{3}{*}{ Season } & \multicolumn{4}{|c|}{ Gompertz } & \multicolumn{4}{|c|}{ Logistic } \\
\hline & & BRS & rogresso & Tem & orano & $\overline{B R S}$ & ogresso & Tem & prano \\
\hline & & FM & DM & $F M$ & DM & $F M$ & DM & FM & DM \\
\hline & & & & & & & & & \\
\hline 1 & 2 & * & * & ns & ns & * & * & * & ns \\
\hline 1 & 3 & * & ns & * & * & * & * & * & * \\
\hline 1 & 4 & * & ns & * & * & * & ns & * & * \\
\hline 1 & 5 & * & ns & * & $\mathrm{ns}$ & * & ns & * & ns \\
\hline 2 & 3 & ns & * & * & ns & * & * & * & * \\
\hline 2 & 4 & * & * & ns & * & ns & * & ns & * \\
\hline 2 & 5 & * & * & ns & ns & ns & * & ns & ns \\
\hline 3 & 4 & * & * & * & ns & $\star$ & * & * & ns \\
\hline 3 & 5 & * & * & * & ns & * & * & 夫 & $\star$ \\
\hline 4 & 5 & * & ns & ns & ns & * & ns & ns & * \\
\hline
\end{tabular}

\begin{tabular}{llllllllll}
1 & 2 & $\mathrm{~ns}$ & $*$ & $\mathrm{~ns}$ & $\mathrm{~ns}$ & $\mathrm{~ns}$ & $*$ & $\mathrm{~ns}$ & $\mathrm{~ns}$ \\
1 & 3 & $\mathrm{~ns}$ & $\mathrm{~ns}$ & $\mathrm{~ns}$ & $\mathrm{~ns}$ & $\mathrm{~ns}$ & $\mathrm{~ns}$ & $\mathrm{~ns}$ & $\mathrm{~ns}$ \\
1 & 4 & $\mathrm{~ns}$ & $\mathrm{~ns}$ & $\mathrm{~ns}$ & $\mathrm{~ns}$ & $\mathrm{~ns}$ & $\mathrm{~ns}$ & $\mathrm{~ns}$ & $\mathrm{~ns}$ \\
1 & 5 & $\mathrm{~ns}$ & $\mathrm{~ns}$ & $\mathrm{~ns}$ & $\mathrm{~ns}$ & $\mathrm{~ns}$ & $\mathrm{~ns}$ & $\mathrm{~ns}$ & $\mathrm{~ns}$ \\
2 & 3 & $\mathrm{~ns}$ & $\mathrm{~ns}$ & $\mathrm{~ns}$ & $\mathrm{~ns}$ & $\mathrm{~ns}$ & $\mathrm{~ns}$ & $\mathrm{~ns}$ & $\mathrm{~ns}$ \\
2 & 4 & $\mathrm{~ns}$ & $\mathrm{~ns}$ & $\mathrm{~ns}$ & $\mathrm{~ns}$ & $\mathrm{~ns}$ & $\mathrm{~ns}$ & $\mathrm{~ns}$ & $\mathrm{~ns}$ \\
2 & 5 & $\mathrm{~ns}$ & $\mathrm{~ns}$ & $\mathrm{~ns}$ & $\mathrm{~ns}$ & $\mathrm{~ns}$ & $\mathrm{~ns}$ & $\mathrm{~ns}$ & $\mathrm{~ns}$ \\
3 & 4 & $\mathrm{~ns}$ & $\mathrm{~ns}$ & $\mathrm{~ns}$ & $\mathrm{~ns}$ & $\mathrm{~ns}$ & $\mathrm{~ns}$ & $\mathrm{~ns}$ & $\mathrm{~ns}$ \\
3 & 5 & $\mathrm{~ns}$ & $\mathrm{~ns}$ & $\mathrm{~ns}$ & $\mathrm{~ns}$ & $\mathrm{~ns}$ & $\mathrm{~ns}$ & $\mathrm{~ns}$ & $\mathrm{~ns}$ \\
4 & 5 & $\mathrm{~ns}$ & $\mathrm{~ns}$ & $\mathrm{~ns}$ & $\mathrm{~ns}$ & $\mathrm{~ns}$ & $\mathrm{~ns}$ & $\mathrm{~ns}$ & $\mathrm{~ns}$ \\
\hline
\end{tabular}

\begin{tabular}{llllllllll}
1 & 2 & ns & $*$ & ns & ns & ns & $*$ & ns & ns \\
1 & 3 & ns & ns & ns & ns & ns & ns & ns & ns \\
1 & 4 & ns & ns & ns & ns & ns & ns & ns & ns \\
1 & 5 & ns & ns & ns & ns & ns & ns & ns & ns \\
2 & 3 & ns & ns & ns & ns & ns & ns & ns & ns \\
2 & 4 & ns & ns & ns & ns & ns & ns & ns & ns \\
2 & 5 & ns & ns & ns & ns & ns & ns & ns & ns \\
3 & 4 & ns & ns & ns & ns & ns & ns & ns & ns \\
3 & 5 & ns & ns & ns & ns & ns & ns & ns & ns \\
4 & 5 & ns & ns & ns & ns & ns & ns & ns & ns \\
\hline
\end{tabular}

${ }^{(1)}$ Comparison of the estimates of the parameters ( $a, b$, and $\left.c\right)$ between sowing seasons: * - Estimates differ at $\mathrm{p} \leq 0.05$; ns - Not significant;

${ }^{(2)}$ Fresh matter of aerial part (FM, in g plant $\left.{ }^{-1}\right)$ and dry matter of aerial part (DM, in g plant $\left.{ }^{-1}\right)$

cultivar must have a higher production in mass to be promising as soil cover and grazing, requiring a higher thermal time and a longer growing cycle.

Analyzing the adjustment quality of the models is important for decision-making to indicate the most appropriate model for each cultivar and sowing season. Thus, it was found that the adjustment quality indicators were always favorable to the Logistic model (higher $\mathrm{R}^{2}$ and lower AIC and RSD), apart from cultivar BRS Progresso in season 1, for dry matter of aerial part, and cultivar Temprano in season 4, for fresh matter of aerial part (Table 5). Muianga et al. (2016) and Muniz et al. (2017) also found favorable quality evaluators for the Logistic model when analyzing the adjustment quality of the models.

Models that exhibit near-linear behavior are preferable to indicate the nonlinear model that best adjusts to the crop. Thus, the nonlinear model can be indicated based on the intrinsic and parameter effect nonlinearity. It was found that the Logistic model is closer to a linear model because it has lower values of intrinsic and parameter effect nonlinearity, which makes it more suitable for the cultivars BRS Progresso and Temprano. 
Seasons 2 and 3 presented the most suitable models for cultivars BRS Progresso and Temprano, respectively, for the fresh matter of aerial part (Figure 1), while seasons 1 and 4

presented the most suitable models for cultivars BRS Progresso and Temprano, respectively, for dry matter of aerial part. In this context, to indicate the best model when testing their

Table 5. Coefficient of determination $\left(\mathrm{R}^{2}\right)$, akaike information criterion (AIC), residual standard deviation (RSD), intrinsic nonlinearity (IN) and the nonlinearity caused by the effect of the parameter (EP), inflection point (IP), maximum acceleration point (MAP), maximum deceleration point (MDP) and the asymptotic deceleration point (ADP) of the Gompertz and Logistic models for traits ${ }^{(1)}$ as a function of the accumulated thermal time $\left({ }^{\circ} \mathrm{C}\right)$ of cultivars BRS Progresso and Temprano in five sowing seasons of rye

\begin{tabular}{|c|c|c|c|c|c|c|c|c|c|}
\hline \multirow{3}{*}{ Statistics } & & FM & DM & FM & DM & FM & DM & FM & DM \\
\hline & & \multicolumn{4}{|c|}{ Gompertz } & \multicolumn{4}{|c|}{ Logistic } \\
\hline & & \multicolumn{2}{|c|}{ BRS Progresso } & \multicolumn{2}{|c|}{ Temprano } & \multicolumn{2}{|c|}{ BRS Progresso } & \multicolumn{2}{|c|}{ Temprano } \\
\hline & & & & & Season1 & $3,2016)$ & & & \\
\hline $\mathrm{R}^{2}$ & & 0.799 & 0.924 & 0.693 & 0.732 & 0.806 & 0.905 & 0.713 & 0.759 \\
\hline AIC & & 3.094 & -0.082 & 3.473 & 1.154 & 3.066 & 0.138 & 3.405 & 1.050 \\
\hline RSD & & 3.898 & 0.796 & 4.841 & 1.525 & 3.834 & 0.893 & 4.680 & 1.444 \\
\hline \multirow{2}{*}{ IP } & $x$ & 788.790 & 1304.321 & 839.293 & 1162.263 & 850.043 & 1475.627 & 1023.401 & 1342.386 \\
\hline & $y$ & 6.327 & 3.739 & 7.076 & 2.566 & 8.566 & 4.630 & 9.668 & 3.466 \\
\hline \multirow{2}{*}{ MAP } & $x$ & 654.587 & 660.975 & 511.945 & 793.246 & 711.293 & 983.455 & 714.046 & 1013.182 \\
\hline & $y$ & 1.255 & 0.741 & 1.403 & 0.509 & 3.621 & 1.957 & 4.086 & 1.465 \\
\hline \multirow{2}{*}{ MDP } & $x$ & 922.993 & 1947.667 & 1166.641 & 1531.280 & 988.793 & 1967.799 & 1332.755 & 1671.590 \\
\hline & $\mathrm{y}$ & 11.739 & 6.936 & 13.128 & 4.761 & 13.512 & 7.304 & 15.249 & 5.468 \\
\hline \multirow{2}{*}{ ADP } & $x$ & 1039.402 & 2505.708 & 1450.584 & 1851.367 & 1091.565 & 2332.352 & 1561.894 & 1915.432 \\
\hline & $y$ & 14.572 & 8.610 & 16.297 & 5.911 & 15.561 & 8.411 & 17.561 & 6.297 \\
\hline IN & & 1.318 & 0.299 & 0.966 & 0.914 & 0.994 & 0.218 & 0.717 & 0.743 \\
\hline \multirow[t]{2}{*}{ EP } & & 2.207 & 1.803 & 2.687 & 3.084 & 1.830 & 0.889 & 2.013 & 2.183 \\
\hline & & \multicolumn{8}{|c|}{ Season2 (May 25, 2016) } \\
\hline $\mathrm{R}^{2}$ & & 0.902 & 0.959 & 0.788 & 0.921 & 0.910 & 0.960 & 0.800 & 0.928 \\
\hline AlC & & 4.974 & 1.401 & 4.509 & 0.056 & 4.906 & 1.371 & 4.454 & -0.037 \\
\hline RSD & & 10.045 & 1.670 & 7.888 & 0.851 & 9.632 & 1.643 & 7.673 & 0.812 \\
\hline \multirow{2}{*}{ IP } & $x$ & 793.309 & 969.901 & 960.150 & 1112.939 & 839.970 & 1077.451 & 1050.439 & 1136.961 \\
\hline & $y$ & 23.500 & 7.314 & 17.251 & 3.895 & 31.929 & 9.589 & 20.206 & 4.061 \\
\hline \multirow{2}{*}{ MAP } & $x$ & 685.016 & 704.693 & 545.218 & 618.335 & 718.021 & 847.941 & 766.681 & 835.159 \\
\hline & $y$ & 4.660 & 1.450 & 3.421 & 0.772 & 13.495 & 4.053 & 8.540 & 1.716 \\
\hline & $x$ & 901.602 & 1235.109 & 1375.082 & 1607.544 & 961.918 & 1306.960 & 1334.196 & 1438.764 \\
\hline IVIDP & $y$ & 43.599 & 13.570 & 32.005 & 7.226 & 50.362 & 15.125 & 31.872 & 6.406 \\
\hline & $x$ & 995.535 & 1465.152 & 1734.996 & 2036.565 & 1052.246 & 1476.958 & 1544.376 & 1662.309 \\
\hline ADP & $\hat{y}$ & 54.122 & 16.845 & 39.729 & 8.970 & 57.998 & 17.418 & 36.704 & 7.377 \\
\hline IN & & 1.313 & 0.415 & 0.957 & 0.563 & 0.719 & 0.369 & 0.691 & 0.392 \\
\hline EP & & 1.799 & 1.107 & 10.414 & 10.611 & 1.332 & 0.913 & 3.902 & 2.974 \\
\hline & & & & & Season3 & $7,2016)$ & & & \\
\hline $\mathrm{R}^{2}$ & & 0.738 & 0.867 & 0.978 & 0.954 & 0.752 & 0.878 & 0.981 & 0.963 \\
\hline AlC & & 5.737 & 1.923 & 2.642 & 0.337 & 5.683 & 1.847 & 2.483 & 0.110 \\
\hline RSD & & 14.592 & 2.175 & 3.101 & 0.981 & 14.200 & 2.086 & 2.864 & 0.875 \\
\hline 然 & $\mathrm{x}$ & 730.931 & 863.978 & 1169.723 & 1224.144 & 804.086 & 935.109 & 1195.525 & 1246.820 \\
\hline $\mathbb{P}$ & $y$ & 19.191 & 4.408 & 28.946 & 6.255 & 26.192 & 5.950 & 30.035 & 6.482 \\
\hline $\mathrm{MAD}$ & $x$ & 609.054 & 711.369 & 606.971 & 724.642 & 685.699 & 784.585 & 846.329 & 945.743 \\
\hline IVIAP & $y$ & 3.805 & 0.874 & 5.740 & 1.240 & 11.070 & 2.515 & 12.694 & 2.740 \\
\hline סחמו & $x$ & 852.808 & 1016.587 & 1732.474 & 1723.645 & 922.472 & 1085.633 & 1544.721 & 1547.897 \\
\hline MDP & $y$ & 35.605 & 8.178 & 53.703 & 11.606 & 41.314 & 9.386 & 47.376 & 10.225 \\
\hline & $x$ & 958.525 & 1148.961 & 2220.607 & 2156.914 & 1010.161 & 1197.126 & 1803.372 & 1770.905 \\
\hline ADP & $y$ & 44.198 & 10.152 & 66.665 & 14.407 & 47.577 & 10.809 & 54.558 & 11.775 \\
\hline IN & & 1.249 & 1.114 & 0.259 & 0.447 & 1.187 & 0.814 & 0.175 & 0.278 \\
\hline EP & & 2.503 & 2.014 & 5.513 & 8.029 & 2.265 & 1.581 & 1.546 & 2.029 \\
\hline & & & & & Season4 & $22,2016)$ & & & \\
\hline $\mathrm{R}^{2}$ & & 0.780 & 0.907 & 0.921 & 0.981 & 0.788 & 0.913 & 0.920 & 0.983 \\
\hline AlC & & 4.753 & 0.975 & 2.854 & -1.180 & 4.720 & 0.915 & 2.864 & -1.290 \\
\hline RSD & & 8.935 & 1.352 & 3.486 & 0.464 & 8.771 & 1.308 & 3.506 & 0.439 \\
\hline & $\mathrm{x}$ & 712.243 & 848.896 & 869.576 & 1466.133 & 755.120 & 931.369 & 1018.724 & 1411.199 \\
\hline IP & $y$ & 12.846 & 3.368 & 12.652 & 5.978 & 17.511 & 4.547 & 15.863 & 5.611 \\
\hline & $x$ & 621.098 & 676.839 & 408.383 & 713.367 & 652.055 & 760.183 & 647.932 & 984.183 \\
\hline MAP & $y$ & 2.547 & 0.668 & 2.509 & 1.185 & 7.401 & 1.922 & 6.704 & 2.372 \\
\hline & $x$ & 803.387 & 1020.954 & 1330.769 & 2218.899 & 858.185 & 1102.556 & 1389.517 & 1838.216 \\
\hline MDP & $\hat{y}$ & 23.833 & 6.248 & 23.473 & 11.090 & 27.621 & 7.172 & 25.022 & 8.851 \\
\hline & $x$ & 882.446 & 1170.197 & 1730.809 & 2871.851 & 934.525 & 1229.355 & 1664.164 & 2154.507 \\
\hline ADP & $\hat{y}$ & 29.585 & 7.757 & 29.139 & 13.767 & 31.809 & 8.259 & 28.815 & 10.193 \\
\hline IN & & 1.256 & 0.780 & 0.434 & 0.216 & 1.184 & 0.630 & 0.333 & 0.144 \\
\hline EP & & 1.934 & 1.633 & 2.929 & 5.859 & 1.942 & 1.337 & 1.588 & 1.358 \\
\hline
\end{tabular}


Table 5 continue

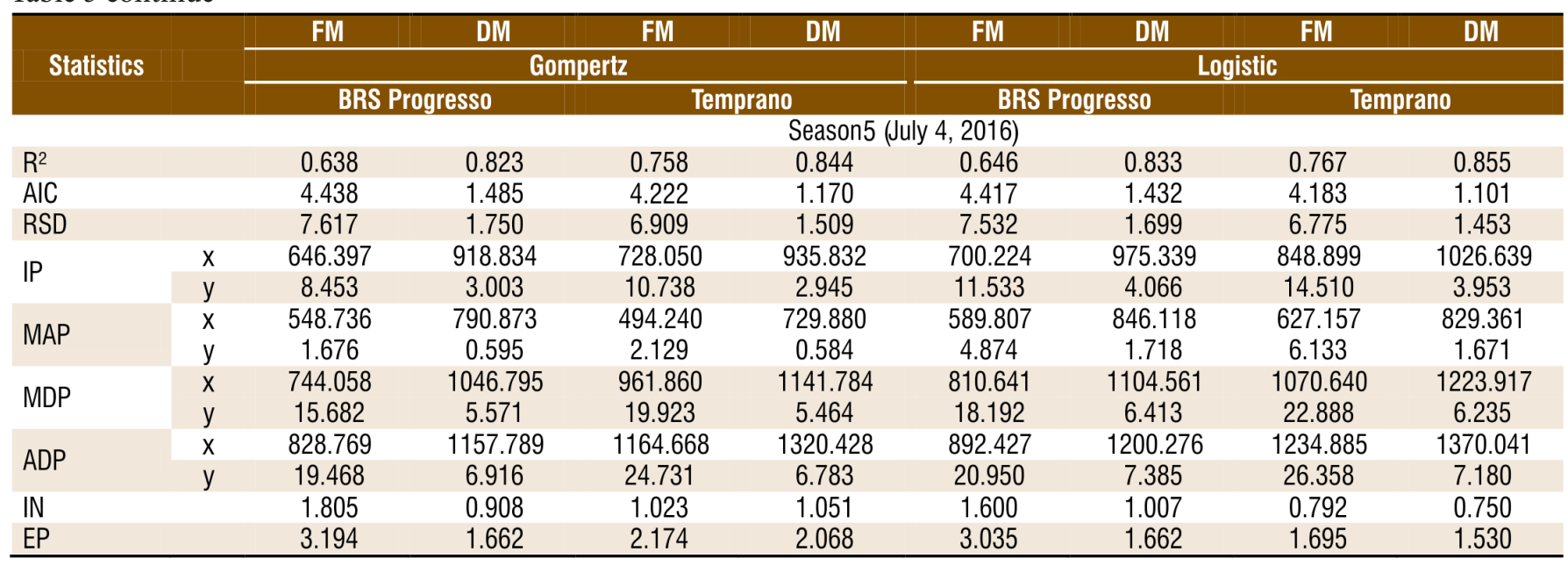

${ }^{(1)}$ Fresh matter of aerial part (FM, in $g$ plant $\left.{ }^{-1}\right)$ and dry matter of aerial part $\left(\mathrm{DM}\right.$, in $\left.\mathrm{g} \mathrm{plant}^{-1}\right)$

BRS Progresso

A. Season 2 (May 25, 2016)

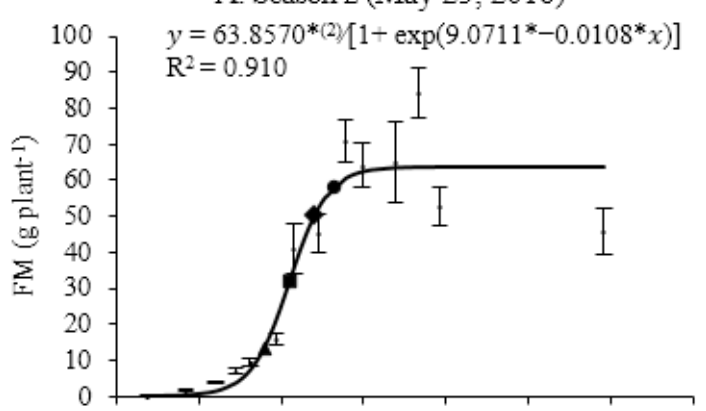

C. Season 1 (May 3, 2016)

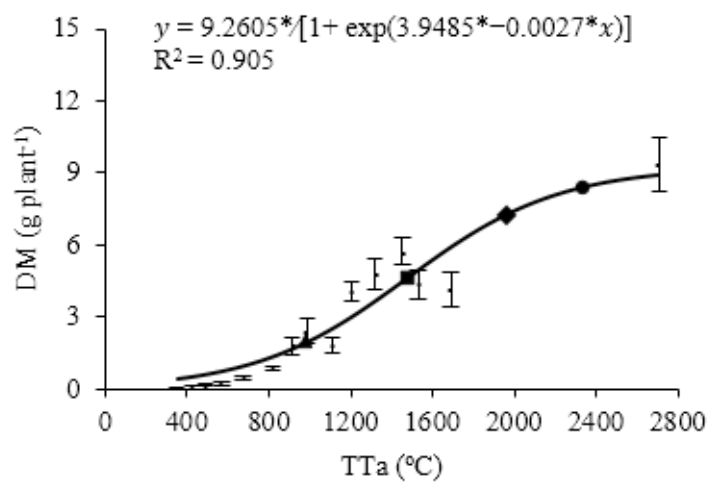

Temprano

B. Season 3 (June 7,2016 )

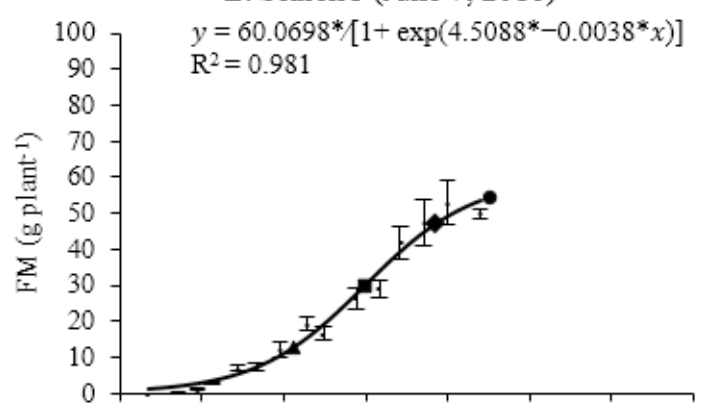

D. Season 4 (June 22, 2016)

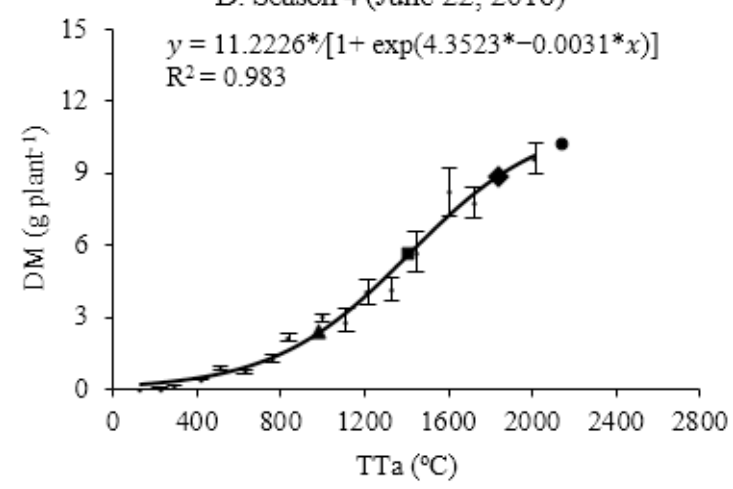

$\Delta \mathrm{MAP}^{(1)} \bullet \mathrm{IP} \bullet \mathrm{MDP} \bullet \mathrm{ADP} \quad \mathrm{I} \quad \mathrm{m} \pm \mathrm{SE}$

${ }^{(1)}$ Inflection point (IP), maximum acceleration point (MAP), maximum deceleration point (MDP), and the asymptotic deceleration point (ADP), mean \pm standard error ( \pm \pm SE), estimated based on 10 rye plants, at each evaluation date of sowing season

(2)* Significant at $\mathrm{p} \leq 0.05$ by t test

Figure 1. Graph of the Logistic model for fresh matter of aerial part (FM, in g plant $\left.{ }^{-1}\right)$ and dry matter of aerial part (DM, in $\left.\mathrm{g} \mathrm{plant}^{-1}\right)$ as a function of the accumulated thermal time (TTa, in ${ }^{\circ} \mathrm{C}$ ) of cultivars BRS Progresso (A and C) and Temprano (B and $\mathrm{D}$ ) in four sowing seasons of rye

linear behaviors, Gazola et al. (2011) evaluated hybrid corn and Fernandes et al. (2014) evaluated coffee using the same evaluators employed in the present study.

In future research on the rye crop, it is suggested using the equation obtained in the present study to verify whether the cultural management is being used at the right moment, for which the thermal time of the crop must be employed in the equation to verify if the trait is in similar conditions for the sowing season and cultivar used in this study. Therefore, to exemplify the crop growth, it was obtained the equation $y=63.8570 / 1+\exp (9.0711-0.0108 x)]$ in the Logistic model for fresh matter of aerial part in function of the accumulated thermal time (TTa) of cultivar BRS Progresso, season 2 (Figure 1). Considering a fictitious thermal time value of $660^{\circ} \mathrm{C}$, the estimated value for fresh matter of aerial part is of $8.01 \mathrm{~g}$ plant $^{-1}$, value inferior to the maximum acceleration point. In this case, the plant would be in growth progression, in which case it would occur until the plant reached the inflection point where it would decelerate its growth. It is up to the researcher to analyze whether or not the plant follows its growth pattern, verifying if the growth is satisfactory for the analyzed sowing season and cultivar. In this sense, the researcher can infer on 
the dry matter of aerial part at different sowing and cultivation seasons to obtain a promising behavior for soil cover or grain production.

Nonlinear growth models are important for choosing the best time for implementing the crop and cultivar to obtain better quality agronomic characteristics. The choice for the Logistic model should be prioritized in rye cultivars for grain production and soil cover when implementing future experiments but the researcher should choose the model that best suits their research perspectives.

This study allows the researcher adequate cultivation by choosing the most appropriate growth model and sowing season for each cultivar. However, the information obtained in the present study is valid for cultivars BRS Progresso and Temprano in the studied environment but may serve as a reference for conducting the crop in future research. Thus, other studies can be performed for other genotypes and environments.

\section{Conclusions}

1. The Gompertz and Logistic models satisfactorily describe the behavior of fresh and dry matter of aerial part of rye cultivars BRS Progresso and Temprano during sowing seasons.

2. The Logistic model best describes the growth of rye cultivars BRS Progresso and Temprano for fresh and dry matter of aerial part.

3. The growth of cultivars BRS Progresso and Temprano is distinct between sowing seasons.

4. Cultivar BRS Progresso requires a lower thermal time until reaching $50 \%$ of its growth when compared to the Temprano cultivar for both Gompertz and Logistic models regarding the fresh and dry matter of aerial part.

\section{Literature Cited}

Arnold, C. Y. Maximum-minimum temperature as a basis for computing heat units. Proceedings of the American Society for Horticultural Science, v.76, p.682-692, 1960.

Bates, D. M.; Watts, D. G. Nonlinear regression analysis and its applications. New York: John Wiley \& Sons, 1988. 384p. https:// doi.org/10.1002/9780470316757

Basche, A. D.; Kaspar, T. C.; Archontoulis, S. V.; Jaymes, D. B.; Sauer, T. J.; Parkin, T. B.; Miguez, F. E. Soil water improvements with the long-term use of a winter rye cover crop. Agricultural Water Management, v.172, p.40-50, 2016. https://doi.org/10.1016/j. agwat.2016.04.006

Bruckner, P. L.; Raymer, P. L. Factors influencing species and cultivar choice of smail grains for winter forage. Journal of Production Agriculture, v.3, p.349-355, 1990. https://doi.org/10.2134/ jpa1990.0349
Deprá, M. S.; Lopes, S. J.; Noal, G.; Reiniger, L. R. S.; Cocco, D. T. Modelo logístico de crescimento de cultivares crioulas de milho e de progênies de meios-irmãos maternos em função da soma térmica. Ciência Rural, v.46, p.36-43, 2016. https://doi. org/10.1590/0103-8478cr20140897

Dourado Neto, D.; Teruel, D. A.; Reichardt, K.; Nielsen, D. R.; Frizzone, J. A.; Bacchi, O. O. S. Principles of crop modeling and simulation. I. Uses of mathematical models in agriculture science. Scientia Agricola, v.55, p.46-50, 1998. https://doi.org/10.1590/ S0103-90161998000500008

Fernandes, T. J.; Pereira, A. A.; Muniz, J. A.; Savian, T. V. Seleção de modelos não lineares para a descrição das curvas de crescimento do fruto do cafeeiro. Coffee Science, v.9, p.207-215, 2014.

Gazola, S.; Scapim, C. A.; Guedes, T. A.; Braccini, A. de L. e. Proposta de modelagem não-linear do desempenho germinativo de sementes de milho híbrido. Ciência Rural, v.41, p.551-556, 2011. https://doi.org/10.1590/S0103-84782011005000022

Gilmore, E. C.; Rogers, J. S. Heat units as a method of measuring maturity in corn. Agronomy Journal, v.50, p.611-615, 1958. https://doi.org/10.2134/agronj1958.00021962005000100014x

Heldwein, A. B.; Buriol, G. A.; Streck, N. A. O clima de Santa Maria. Ciência \& Ambiente. v.38, p.43-58, 2009.

Large, E. C. Growth stages in cereals illustration of the feeks scales.Plant Pathology, v.4, p.128-129, 1954. https://doi. org/10.1111/j.1365-3059.1954.tb00716.x

Meinerz, G. R.; Olivo, C. J.; Viégas, J.; Nörnberg, J. L.; Agnolin, C. A.; Scheibler, R. B.; Horst, T.; Fontaneli, R. S. Silagem de cereais de inverno submetidos ao manejo de duplo propósito.Revista Brasileira de Zootecnia, v.40, p.2097-2104, 2011. https://doi. org/10.1590/S1516-35982011001000005

Mischan, M. M.; Pinho, S. Z de. Modelos não lineares: Funções assintóticas de crescimento. São Paulo: Cultura Acadêmica, 2014. 184p.

Muianga, C. A; Muniz, J. A.; Nascimento, M. da S.; Fernandes, T. J.; Savian, T. V. Descrição da curva de crescimento de frutos do cajueiro por modelos não lineares. Revista Brasileira de Fruticultura, v.38, p.22-32, 2016. https://doi.org/10.1590/01002945-295/14

Muniz, J. A.; Nascimento, M. S. da; Fernandes, T. J. Nonlinear models for description of cacao fruit growth with assumption violations. Revista Caatinga, v.30, p.250-257, 2017. https://doi. org/10.1590/1983-21252017v30n128rc

Nelder, J. A.The fitting of a generalization of the logistic curve. Biometrics, v.17, p.89-110, 1961. https://doi.org/10.2307/2527498

R Development Core Team. R: A language and environment for statistical computing. Vienna: R Foundation for Statistical Computing, 2018. sp.

Ratkowsky, D. A. Nonlinear regression modeling. New York: Marcel Dekker, 1983. 276p.

Windsor, C. P. The Gompertz curve as a growth curve. Proceedings of the National Academy of Sciences of the United States of America, v.18, p.1-8, 1932. https://doi.org/10.1073/pnas.18.1.1 